Article

\title{
Novel Antiviral and Antibacterial Activities of Hibiscus schizopetalus
}

\author{
Riham A. El-Shiekh ${ }^{1}\left(0\right.$, Usama Ramadan Abdelmohsen ${ }^{2,3}{ }^{\circledR}$, Hossam M. Ashour ${ }^{4,5, *}$ \\ and Rehab M. Ashour 1,*(D) \\ 1 Department of Pharmacognosy, Faculty of Pharmacy, Cairo University, Cairo 11562, Egypt; \\ Riham.adel@pharma.cu.edu.eg \\ 2 Department of Pharmacognosy, Faculty of Pharmacy, Deraya University, New Minia City 61111, Egypt; \\ Usama.ramadan@mu.edu.eg \\ 3 Department of Pharmacognosy, Faculty of Pharmacy, Minia University, Minia 61519, Egypt \\ 4 Department of Integrative Biology, College of Arts and Sciences, University of South Florida, St. Petersburg, \\ FL 33701, USA \\ 5 Department of Microbiology and Immunology, Faculty of Pharmacy, Cairo University, Cairo 11562, Egypt \\ * Correspondence: hossamking@mailcity.com (H.M.A.); Rehab.ashour@pharma.cu.edu.eg (R.M.A.)
}

Received: 25 September 2020; Accepted: 20 October 2020; Published: 30 October 2020

\begin{abstract}
Hibiscus schizopetalus (Dyer) Hook.f. (Malvaceae) is an ornamental plant. The aim was to investigate its antimicrobial and antioxidant activities. In vitro antiviral, antibacterial, and antioxidant activities of the $70 \%$ ethanolic extract (Et-E) of the aerial parts of the plant were determined. The Dichloromethane Fraction (DCM-F) and the $n$-Butanol Fraction (Bu-F) were assessed using Liquid chromatography-mass spectrometry (LC-MS). The DCM-F showed higher antiviral activities against Coxsackie B4 (CoxB4) viruses $\left(\mathrm{IC}_{50}=64.13 \mu \mathrm{g} / \mathrm{mL}\right)$ and adenoviruses $\left(\mathrm{IC}_{50}=54.88 \mu \mathrm{g} / \mathrm{mL}\right)$ than acyclovir $\left(\mathrm{IC}_{50}=72.79 \mu \mathrm{g} / \mathrm{mL}\right.$ for CoxB4 viruses; $\mathrm{IC}_{50}=91.92 \mu \mathrm{g} / \mathrm{mL}$ for adenoviruses). The DCM-F showed higher anti-helicobacter pylori activity $(\mathrm{MIC}=3.9 \mu \mathrm{g} / \mathrm{mL})$ than clarithromycin (MIC $=1.95 \mu \mathrm{g} / \mathrm{mL})$. The DCM-F inhibited Herpes Simplex Virus (HSV) Type I $\left(\mathrm{IC}_{50}=29.85 \mu \mathrm{g} / \mathrm{mL}\right)$ and HSV Type II $\left(\mathrm{IC}_{50}=74.17 \mu \mathrm{g} / \mathrm{mL}\right)$. The Bu-F showed higher anti-mycobacterial activity $(\mathrm{MIC}=7.81 \mu \mathrm{g} / \mathrm{mL})$ than isoniazid $(\mathrm{MIC}=0.24 \mu \mathrm{g} / \mathrm{mL})$ and higher antibacterial activity against methicillin-resistant Staphylococcus aureus (MRSA)(MIC $=7.81 \mu \mathrm{g} / \mathrm{mL})$ than vancomycin $(\mathrm{MIC}=3.9 \mu \mathrm{g} / \mathrm{mL})$. Antioxidant assays included total antioxidant capacity (TAC), 2,2' -azino-bis-3-ethylbenzthiazoline-6-sulphonic acid (ABTS), 2,2-diphenyl-1-picryl-hydrazyl (DPPH), and iron reducing power. The Bu-F showed the highest antioxidant activity. Chemical profiles were analyzed using HPLC-HR-ESI-MS to identify the metabolites responsible for these biological activities. We identified more than 60 metabolites that belong to anthocyanins, flavonoids, phenolics, terpenes, sterols, and fatty acids. In conclusion, Hibiscus schizopetalus is endowed with metabolites that could be used against viruses and antibiotic-resistant bacteria. They can also be potent antioxidants.
\end{abstract}

Keywords: Hibiscus schizopetalus; antioxidant; antiviral; antimicrobial; anthocyanins; LC-MS

\section{Introduction}

Antimicrobial resistance to classical antibiotics is a major problem that negatively impacts treatments of common infectious diseases caused by fungi, bacteria, viruses, and parasites. In order to overcome this major problem, natural products offer a viable alternative [1].

Hibiscus is a member of Malvaceae family and is cultivated globally as an ornamental and medicinal plant [2]. It is typically distributed in tropical and subtropical regions. Hibiscus species have long been known for their economic and therapeutic importance [3]. Hibiscus schizopetalus (Dyer) 
Hook.f.; commonly known as coral Hibiscus; is a shrub that has highly attractive solitary, hanging, and bright red flowers [4,5]. It is indigenous to tropical East Africa [4] and is commonly known as coral Hibiscus or fringed Hibiscus. H. schizopetalus leaves have had a traditional use in treating spermatorrhea. Its flowers have been applied to the scalp as hair tonics. Its fruits have been used in the management of urinary tract problems caused by endocrinological ailments. Different parts of the plant have been used in the treatment of cold, cough, and fever [2,6]. Previous pharmacological studies suggested hypolipidemic, analgesic, hypoglycemic, antipyretic, and anti-inflammatory actions for H. schizopetalus but there are no studies that established its activity against the list of bacteria and viruses included in this study [7]. The major constituents of H. schizopetalus are anthocyanins, sterols, triterpenes, and phenolics $[3,7,8]$.

Previous studies on other Hibiscus species such as Hibiscus sabdariffa and Hibiscus rosa sinensis flowers reported activities against methicillin-resistant Staphylococcus aureus (MRSA) [9,10]. This has not been established for $H$. schizopetalus. Finding new antibacterial and antiviral medications has become very important nowadays in order to be able to face the escalating problem of bacterial resistance. Natural agents, known for lower toxicity and higher effectiveness, are potential alternatives to more toxic and less effective treatments. Antiviral drugs act through inhibiting viral fusion, integration, protease, uncoating, nucleic acid synthesis, and viral release [11].

Newly discovered natural medications that can be used for the treatment and prophylactic of bacterial and viral infections can be viable and safer alternatives to traditional medications. These biologically active metabolites identified from natural products may offer several advantages over synthetic ones including lower toxicity, more biodegradability, and lower costs. Plants are a rich source of bioactive compounds that can lead to the development of new, natural drugs that can have novel mechanisms. This is especially important given the spread of antimicrobial resistance.

The aim of the study was to assess the antiviral, antibacterial, and antioxidant activities of $H$. schizopetalus. In order to accomplish these aims, we tested the $70 \%$ ethanolic extract, the methylene chloride fraction, and the $n$-butanol fraction. In addition, their chemical profiles were analyzed by HPLC-HR-ESI-MS. These studies are important in the development of new promising anti-infective agents.

\section{Results}

\subsection{Cytotoxicity Assay}

The $50 \%$ cytotoxic concentration $\left(\mathrm{CC}_{50}\right)$ of the $70 \%$ ethanolic extract (Et-E), the Dichloromethane Fraction (DCM-F), and the $n$-Butanol Fraction (Bu-F) were $230.80,325.92$, and $288.45 \mu \mathrm{g} / \mathrm{mL}$, respectively, whereas the maximum non-toxic concentration (MNTC) on Vero cells was estimated to be $78.12 \mathrm{ug} / \mathrm{mL}$. This was used for testing the antiviral activities of $H$. schizopetalus.

\subsection{Antiviral Activity}

The antiviral activity of Et-E was tested using three different protocols. Results are reported using the half maximal inhibitory concentration $\left(\mathrm{IC}_{50}\right.$ ) (Table 1). At a concentration of $78.12 \mathrm{ug} / \mathrm{mL}$, the Et-E significantly inhibited adenoviruses and Coxsackie B4 (CoxB4) viruses in protocol C by $72.94 \%$ and $54.24 \%$, respectively compared to acyclovir inhibitions of $61.35 \%$ and $53.9 \%$, respectively. In contrast, mild to weak antiviral activity was observed against HSVI, HSVII, and HAV viruses. The Et-E showed weak activity with protocols $\mathrm{A}$ and $\mathrm{B}$. Thus, protocol $\mathrm{C}$ was selected for further investigations.

Using protocol C, Et-E, DCM-F, and Bu-F (Tables 1 and 2) were further examined. DCM-F showed the highest antiviral activity against adenoviruses and CoxB4 viruses, which was higher than Et-E and acyclovir. The DCM-F inhibited adenovirus by an $\mathrm{IC}_{50}$ of $54.88 \mu \mathrm{g} / \mathrm{mL}$, compared to acyclovir's $\mathrm{IC}_{50}$ of $91.92 \mu \mathrm{g} / \mathrm{mL}$. The DCM-F inhibited CoxB4 virus by an $\mathrm{IC}_{50}$ of $64.13 \mu \mathrm{g} / \mathrm{mL}$ compared to acyclovir's $\mathrm{IC}_{50}$ of $72.79 \mu \mathrm{g} / \mathrm{mL}$. Additionally, the DCM-F inhibited HSVI virus $\left(\mathrm{IC}_{50}=29.85 \mu \mathrm{g} / \mathrm{mL}\right)$, compared to 
acyclovir's IC $_{50}$ of $26.99 \mu \mathrm{g} / \mathrm{mL}$. DCM-F inhibited HSVII (IC 50 of $74.17 \mu \mathrm{g} / \mathrm{mL}$ ), compared to acyclovir's $\mathrm{IC}_{50}$ of $68.60 \mu \mathrm{g} / \mathrm{mL}$. DCM-F showed no activity against hepatitis A virus.

Table 1. Antiviral activity of Hibiscus schizopetalus.

\begin{tabular}{|c|c|c|c|c|c|c|}
\hline Name of Virus & Protoc & & Protoc & & Proto & $\mathrm{C}$ \\
\hline \multirow{4}{*}{ Adenovirus } & \multirow{3}{*}{ Et-E } & \multirow{3}{*}{39.66} & \multirow{3}{*}{ Et-E } & \multirow{3}{*}{58.40} & Et-E & $72.94^{\mathrm{c}}$ \\
\hline & & & & & DCM-F & $78.78^{d}$ \\
\hline & & & & & $\mathrm{Bu}-\mathrm{F}$ & $33.41^{\mathrm{a}}$ \\
\hline & Acyclovir & 41.95 & Acyclovir & 59.90 & Acyclovir & $61.35^{b}$ \\
\hline \multirow{4}{*}{ CoxB4 } & \multirow{3}{*}{ Et-E } & \multirow{3}{*}{33.25} & \multirow{3}{*}{ Et-E } & \multirow{3}{*}{22.50} & Et-E & $54.24^{b}$ \\
\hline & & & & & DCM-F & $60.90^{c}$ \\
\hline & & & & & $\mathrm{Bu}-\mathrm{F}$ & $33.96^{\mathrm{a}}$ \\
\hline & Acyclovir & 41.50 & Acyclovir & 36.32 & Acyclovir & $53.90^{b}$ \\
\hline \multirow{4}{*}{ HSV I } & \multirow{3}{*}{ Et-E } & \multirow{3}{*}{47.57} & \multirow{3}{*}{ Et-E } & \multirow{3}{*}{25.90} & Et-E & $62.67^{\mathrm{a}}$ \\
\hline & & & & & DCM-F & $91.80^{\mathrm{c}}$ \\
\hline & & & & & $\mathrm{Bu}-\mathrm{F}$ & $80.79^{b}$ \\
\hline & Acyclovir & 75.20 & Acyclovir & 42.33 & Acyclovir & $95.48^{c}$ \\
\hline \multirow{4}{*}{ HSV II } & \multirow{3}{*}{ Et-E } & \multirow{3}{*}{9.49} & \multirow{3}{*}{ Et-E } & \multirow{3}{*}{27.79} & Et-E & $30.84^{b}$ \\
\hline & & & & & DCM-F & $51.75^{\mathrm{c}}$ \\
\hline & & & & & $\mathrm{Bu}-\mathrm{F}$ & $1.78^{a}$ \\
\hline & Acyclovir & 23.05 & Acyclovir & 46.44 & Acyclovir & $55.69^{d}$ \\
\hline \multirow{4}{*}{ HAV } & \multirow{3}{*}{ Et-E } & \multirow{3}{*}{0.55} & \multirow{3}{*}{ Et-E } & \multirow{3}{*}{0} & Et-E & $12.10^{b}$ \\
\hline & & & & & DCM-F & $18.28^{c}$ \\
\hline & & & & & $\mathrm{Bu}-\mathrm{F}$ & $5.60^{\mathrm{a}}$ \\
\hline & Acyclovir & 21.60 & Acyclovir & 0 & Acyclovir & $30.47^{d}$ \\
\hline
\end{tabular}

The percentage of inhibition was determined at a concentration of $78.12 \mu \mathrm{g} / \mathrm{mL}$. Different superscripts $(\mathrm{a}, \mathrm{b}, \mathrm{c} \& \mathrm{~d})$ for a given value within a column indicate significant difference at $p<0.05$ using Duncan's Multiple Range test (DMRT). Ethanolic Extract (Et-E); Dichloromethane Fraction (DCM-F); $n$-Butanol Fraction (Bu-F); Coxsackie (CoxB4); Herpes Simplex Virus Type I (HSV-I); Herpes Simplex Virus Type II (HSV-II); Hepatitis A Virus (HAV). Protocol A: Virus pretreatment; Protocol B: Cell pretreatment; Protocol C: Post-infection treatment.

Table 2. $\mathrm{IC}_{50}(\mu \mathrm{g} / \mathrm{mL})$ and selectivity index (SI) of Hibiscus schizopetalus by protocol C.

\begin{tabular}{|c|c|c|c|c|c|}
\hline \multirow{2}{*}{ Virus } & \multirow{2}{*}{ Parameter } & \multicolumn{3}{|c|}{ Sample } & \multirow{2}{*}{$\begin{array}{l}\text { Standard } \\
\text { Acyclovir }\end{array}$} \\
\hline & & Et-E & DCM-F & Bu-F & \\
\hline \multirow{2}{*}{ Adenovirus } & $\mathrm{IC}_{50}$ & $58.89^{b}$ & $54.88^{a}$ & $108.31^{\mathrm{d}}$ & $91.92^{c}$ \\
\hline & SI & 3.8 & 5.93 & 2.66 & 8.34 \\
\hline \multirow{2}{*}{ CoxB4 } & $\mathrm{IC}_{50}$ & $72.0^{b}$ & $64.13^{a}$ & $107.30^{c}$ & $72.79^{b}$ \\
\hline & SI & 3.20 & 5.08 & 2.68 & 10.53 \\
\hline \multirow{2}{*}{ HSV I } & $\mathrm{IC}_{50}$ & $66.86^{d}$ & $29.85^{b}$ & $50.94^{c}$ & $26.99^{a}$ \\
\hline & SI & 3.45 & 10.91 & 5.66 & 28.42 \\
\hline \multirow{2}{*}{ HSVII } & $\mathrm{IC}_{50}$ & $126.65^{c}$ & $74.17^{b}$ & - & $68.60^{a}$ \\
\hline & $\mathrm{SI}$ & 1.82 & 4.39 & & 11.18 \\
\hline \multirow{2}{*}{ HAV } & $\mathrm{IC}_{50}$ & - & $168.67^{b}$ & - & $95.40^{a}$ \\
\hline & SI & & 1.93 & & 8.04 \\
\hline
\end{tabular}

The half maximal inhibitory concentration $\left(\mathrm{IC}_{50}\right.$ ) was calculated in $\mu \mathrm{g} / \mathrm{mL}$; selectivity index (SI). Different superscripts $(a, b, c \& d)$ for a given value within a column indicate significant difference at $p<0.05$ using Duncan's Multiple Range test (DMRT). Ethanolic Extract (Et-E); Dichloromethane Fraction (DCM-F); n-Butanol Fraction (Bu-F). Coxsackie Virus (CoxB4); Herpes Simplex Virus Type I (HSV-I); Herpes Simplex Virus Type II (HSV-II); Hepatitis A Virus (HAV). 


\subsection{Activity against Helicobacter Pylori}

The DCM-F showed the highest antibacterial activity against Helicobacter pylori with an MIC90 of $2.9 \mu \mathrm{g} / \mathrm{mL}$ and MIC of $3.9 \mu \mathrm{g} / \mathrm{mL}$, compared to clarithromycin's MIC90 of $0.7 \mu \mathrm{g} / \mathrm{mL}$ and MIC of $1.95 \mu \mathrm{g} / \mathrm{mL}$. The anti-H. pylori activity of the DCM-F (MIC $3.9 \mu \mathrm{g} / \mathrm{mL}$ ) was higher than Bu-F (MIC $15.63 \mu \mathrm{g} / \mathrm{mL}$ ), and Et-E (MIC $62.5 \mu \mathrm{g} / \mathrm{mL}$ ). Full results are presented in Table 3.

Table 3. Antibacterial activity of Hibiscus schizopetalus.

\begin{tabular}{ccccccc}
\hline \multirow{2}{*}{ Sample/Standard } & \multicolumn{2}{c}{ Helicobacter pylori } & Mycobacterium & tuberculosis & \multicolumn{2}{c}{ MRSA } \\
\cline { 2 - 7 } & MIC90 & MIC & MIC90 & MIC & MIC90 & MIC \\
\hline Et-E & $22.7^{\mathrm{c}}$ & $62.5^{\mathrm{c}}$ & $98.6^{\mathrm{d}}$ & $125^{\mathrm{d}}$ & $17.56^{\mathrm{b}}$ & $31.25^{\mathrm{c}}$ \\
DCM-F & $2.9^{\mathrm{a}}$ & $3.9^{\mathrm{a}}$ & $12.3^{\mathrm{c}}$ & $15.63^{\mathrm{c}}$ & $44.4^{\mathrm{c}}$ & $62.5^{\mathrm{d}}$ \\
Bu-F & $13.7^{\mathrm{b}}$ & $15.63^{\mathrm{b}}$ & $5.6^{\mathrm{b}}$ & $7.81^{\mathrm{b}}$ & $3.7^{\mathrm{a}}$ & $7.81^{\mathrm{b}}$ \\
Clarithromycin & $0.7^{\mathrm{a}}$ & $1.95^{\mathrm{a}}$ & - & - & - & - \\
Isoniazid & - & - & $0.04^{\mathrm{a}}$ & $0.24^{\mathrm{a}}$ & - & - \\
Vancomycin & - & - & - & - & $2.23^{\mathrm{a}}$ & $3.9^{\mathrm{a}}$ \\
\hline
\end{tabular}

MIC and MIC90 values were calculated in $\mu \mathrm{g} / \mathrm{mL}$ Ethanolic Extract (Et-E); Dichloromethane Fraction (DCM-F); $n$-Butanol Fraction. (Bu-F); Methicillin-resistant Staphylococcus aureus (MRSA). Different superscripts (a, b, c \& d) for a given value within a column indicate significant difference at $p<0.05$ using Duncan's Multiple Range test (DMRT).

\subsection{Anti-Mycobacterial Activity}

The Bu-F showed the highest antibacterial activity against Mycobacterium tuberculosis (M. tuberculosis) with MIC90 of $5.6 \mu \mathrm{g} / \mathrm{mL}$ and MIC of $7.81 \mu \mathrm{g} / \mathrm{mL}$, compared to isoniazid's MIC90 of $0.04 \mu \mathrm{g} / \mathrm{mL}$ and MIC of $0.24 \mu \mathrm{g} / \mathrm{mL}$. The Et-E and DCM-F showed much weaker activities. The results are presented in Table 3.

\subsection{Activity against Methicillin-Resistant Staphylococcus aureus (MRSA)}

The Bu-F showed the highest anti-MRSA activity than other tested samples with MIC90 of $3.7 \mu \mathrm{g} / \mathrm{mL}$ and MIC of $7.81 \mu \mathrm{g} / \mathrm{mL}$, compared to vancomycin's MIC90 of $2.23 \mu \mathrm{g} / \mathrm{mL}$ and MIC of $3.9 \mu \mathrm{g} / \mathrm{mL}$. MRSA was resistant to Et-E and its DCM-F. The results are presented in Table 3.

\subsection{Antioxidant Activity}

The total antioxidant activities of Et-E, DCM-F, and Bu-F were assessed. The Bu-F showed the highest activity followed by the Et-E, and then DCM-F. The Bu-F showed the highest activity percent 2050.5 expressed as a ascorbic acid equivalent in TAC. Bu-F also showed potent scavenging activity by ABTS assay $(151.48 \mu \mathrm{g} / \mathrm{mL})$ and DPPH assay $(271.68 \mu \mathrm{g} / \mathrm{mL})$ as compared to ascorbic acid's $57.76 \mu \mathrm{g} / \mathrm{mL}$ for ABTS and $19.5 \mu \mathrm{g} / \mathrm{mL}$ for DPPH. Using the iron reducing power assay, Bu-F showed a good reduction power $(114.47 \mu \mathrm{g} / \mathrm{mL})$ compared to ascorbic acid $(22 \mu \mathrm{g} / \mathrm{mL})$. Results are shown in Table 4 .

Table 4. Antioxidant activity of Hibiscus schizopetalus.

\begin{tabular}{ccccc}
\hline \multirow{2}{*}{ Sample/Standard } & TAC $\%$ & ABTS & DPPH & Iron Reducing Power \\
\cline { 2 - 5 } & $\mathbf{( A A E )}$ & \multicolumn{2}{c}{ IC $_{\mathbf{5 0}}(\mu \mathrm{g} / \mathbf{m L})$} & EC $_{\mathbf{5 0}}(\boldsymbol{\mu g} / \mathbf{m L})$ \\
\hline Et-E & $1850.83^{\mathrm{b}}$ & $710.51^{\mathrm{c}}$ & $473.29^{\mathrm{c}}$ & $391.45^{\mathrm{c}}$ \\
\hline DCM-F & $800.16^{\mathrm{c}}$ & $819.51^{\mathrm{d}}$ & $1118.92^{\mathrm{d}}$ & $528.0^{\mathrm{d}}$ \\
\hline Bu-F & $2050.50^{\mathrm{a}}$ & $151.48^{\mathrm{b}}$ & $271.68^{\mathrm{b}}$ & $114.47^{\mathrm{b}}$ \\
\hline Ascorbic acid & - & $57.76^{\mathrm{a}}$ & $19.50^{\mathrm{a}}$ & $22^{\mathrm{a}}$ \\
\hline
\end{tabular}

Different superscripts (a, b, c \& d) for a given value within a column indicate significant difference at $p<0.05$ using Duncan's Multiple Range test (DMRT). Ascorbic Acid Equivalent (AAE); Ethanolic Extract (Et-E); Dichloromethane Fraction (DCM-F); $n$-Butanol Fraction (Bu-F). 


\subsection{HPLC-HR-ESI-MS}

Metabolic profiling using LC-HR-ESI-MS for dereplication purposes [12] led to the identification of more than 60 metabolites and bioactive compounds belonging to different classes such as anthocyanins, flavonoids, phenolic acids, terpenes, sterols, and fatty acids. The detected phytochemicals were tentatively identified by searching DNP and METLIN (Table 5 and Figures 1-3).

Table 5. Metabolites of Hibiscus schizopetalus (identified by HPLC-HR-ESI-MS).

\begin{tabular}{|c|c|c|c|c|c|}
\hline Metabolite & $\begin{array}{l}\text { Molecular } \\
\text { Formula }\end{array}$ & Exact Mass & Et-E & DCM-F & Bu-F \\
\hline \multicolumn{6}{|c|}{ Anthocyanins } \\
\hline Cyanidin & $\mathrm{C}_{15} \mathrm{H}_{10} \mathrm{O}_{6}$ & 286.177914 & + & ++ & ++ \\
\hline Cyanidin $O$-rhamnoside & $\mathrm{C}_{21} \mathrm{H}_{20} \mathrm{O}_{10}$ & 432.385735 & + & +++ & ++ \\
\hline Cyanidin $O$-galactoside/Cyanidin $O$-glucoside & $\mathrm{C}_{21} \mathrm{H}_{20} \mathrm{O}_{11}$ & 448.956000 & +++ & ++ & ++ \\
\hline Cyanidin 3-sambubioside & $\mathrm{C}_{26} \mathrm{H}_{28} \mathrm{O}_{15}$ & 580.761473 & + & +++ & + \\
\hline Cyanidin $O$-rutinoside & $\mathrm{C}_{27} \mathrm{H}_{30} \mathrm{O}_{15}$ & 594.399238 & + & + & +++ \\
\hline Cyanidin di- $O$-glucoside & $\mathrm{C}_{27} \mathrm{H}_{30} \mathrm{O}_{16}$ & 610.308112 & + & ++ & + \\
\hline Cyanidin 3-(digalloylglucoside) & $\mathrm{C}_{35} \mathrm{H}_{28} \mathrm{O}_{19}$ & 752.646798 & + & ++ & + \\
\hline Cyanidin 3-(acetylgalloylgalactoside) & $\mathrm{C}_{30} \mathrm{H}_{26} \mathrm{O}_{16}$ & 642.403723 & + & +++ & + \\
\hline $\begin{array}{l}\text { Gossypetin } \\
\end{array}$ & $\mathrm{C}_{15} \mathrm{H}_{10} \mathrm{O}_{8}$ & 318.287501 & + & +++ & + \\
\hline Cyanidin 3-(O-succinoyl-glucopyranoside) & $\mathrm{C}_{25} \mathrm{H}_{24} \mathrm{O}_{14}$ & 548.577150 & + & ++ & + \\
\hline Cyanidin 3-(oxalylglucoside) & $\mathrm{C}_{23} \mathrm{H}_{20} \mathrm{O}_{14}$ & 520.445023 & + & +++ & + \\
\hline Cyanidin 3-(cinnamoylglucoside) & $\mathrm{C}_{30} \mathrm{H}_{26} \mathrm{O}_{12}$ & 578.566536 & + & +++ & + \\
\hline Cyanidin 3-(malonylxyloside) & $\mathrm{C}_{23} \mathrm{H}_{20} \mathrm{O}_{13}$ & 504.916039 & + & +++ & + \\
\hline Cyanidin 3-(xylosylarabinoside) & $\mathrm{C}_{25} \mathrm{H}_{26} \mathrm{O}_{14}$ & 550.464496 & + & +++ & + \\
\hline $\begin{array}{c}\text { Gossypetin glucoside } \\
\text { (Gossypitrin)/Myricetin-O-glucoside }\end{array}$ & $\mathrm{C}_{21} \mathrm{H}_{20} \mathrm{O}_{13}$ & 480.861466 & + & + & +++ \\
\hline Gossypetin glucuronide & $\mathrm{C}_{21} \mathrm{H}_{18} \mathrm{O}_{14}$ & 494.876248 & + & + & +++ \\
\hline Delphinidin & $\mathrm{C}_{15} \mathrm{H}_{10} \mathrm{O}_{7}$ & 302.192080 & + & + & +++ \\
\hline Delphinidin galactoside/Delphinidin glucoside & $\mathrm{C}_{21} \mathrm{H}_{20} \mathrm{O}_{12}$ & 464.370561 & + & + & +++ \\
\hline Delphinidin 3-sambubioside (Hibiscin) & $\mathrm{C}_{26} \mathrm{H}_{28} \mathrm{O}_{16}$ & 596.714621 & ++ & ++ & +++ \\
\hline $\begin{array}{c}\text { Delphinidin neohesperidoside/Delphinidin } \\
\text { rutinoside }\end{array}$ & $\mathrm{C}_{27} \mathrm{H}_{30} \mathrm{O}_{16}$ & 610.371790 & + & + & +++ \\
\hline Dimethyl-delphinidin-glucosyl acetate & $\mathrm{C}_{25} \mathrm{H}_{26} \mathrm{O}_{13}$ & 534.494206 & + & +++ & + \\
\hline Delphinidin 3-gentiobioside & $\mathrm{C}_{27} \mathrm{H}_{29} \mathrm{O}_{17}$ & 626.404530 & + & +++ & + \\
\hline Hibicuslide C & $\mathrm{C}_{13} \mathrm{H}_{12} \mathrm{O}_{4}$ & 232.493625 & + & + & + \\
\hline Hibiscetin & $\mathrm{C}_{15} \mathrm{H}_{10} \mathrm{O}_{9}$ & 334.283647 & + & ++ & + \\
\hline Hibiscetin glucoside & $\mathrm{C}_{21} \mathrm{H}_{20} \mathrm{O}_{14}$ & 496.438349 & + & +++ & + \\
\hline Hibiscus lactone (Hydroxycitric acid lactone) & $\mathrm{C}_{6} \mathrm{H}_{6} \mathrm{O}_{7}$ & 190.177052 & + & +++ & + \\
\hline Hibiscus acid hydroxyethyldimethylether & $\mathrm{C}_{10} \mathrm{H}_{16} \mathrm{O}_{8}$ & 264.266440 & + & + & +++ \\
\hline Hibiscus acid hydroxyethylether & $\mathrm{C}_{8} \mathrm{H}_{12} \mathrm{O}_{8}$ & 236.156126 & + & + & +++ \\
\hline Malvidin & $\mathrm{C}_{17} \mathrm{H}_{14} \mathrm{O}_{7}$ & 330.249624 & + & +++ & + \\
\hline Malvidin $O$-(coumaroylglucoside) & $\mathrm{C}_{32} \mathrm{H}_{30} \mathrm{O}_{14}$ & 638.416871 & + & + & +++ \\
\hline Petunidin & $\mathrm{C}_{16} \mathrm{H}_{12} \mathrm{O}_{7}$ & 316.269633 & + & +++ & + \\
\hline Pelargonidin & $\mathrm{C}_{15} \mathrm{H}_{10} \mathrm{O}_{5}$ & 270.221390 & + & ++ & + \\
\hline Pelargonidin glucoside & $\mathrm{C}_{21} \mathrm{H}_{20} \mathrm{O}_{10}$ & 432.385735 & + & +++ & + \\
\hline
\end{tabular}


Table 5. Cont.

\begin{tabular}{|c|c|c|c|c|c|}
\hline Metabolite & $\begin{array}{l}\text { Molecular } \\
\text { Formula }\end{array}$ & Exact Mass & Et-E & DCM-F & Bu-F \\
\hline \multicolumn{6}{|c|}{ Flavonoids/Phenolic acids } \\
\hline Kaempferol & $\mathrm{C}_{15} \mathrm{H}_{10} \mathrm{O}_{6}$ & 286.194597 & + & + & + \\
\hline Kaempferol rhamnoside & $\mathrm{C}_{22} \mathrm{H}_{22} \mathrm{O}_{10}$ & 446.215495 & + & - & +++ \\
\hline Kaempferol $O$-glucuronide & $\mathrm{C}_{21} \mathrm{H}_{18} \mathrm{O}_{12}$ & 462.214878 & + & - & +++ \\
\hline Kaempferol-3-O-glucuronic acid methyl ether & $\mathrm{C}_{18} \mathrm{H}_{18} \mathrm{O}_{14}$ & 476.012800 & + & + & + \\
\hline Kaempferol $O$-rutinoside & $\mathrm{C}_{27} \mathrm{H}_{30} \mathrm{O}_{15}$ & 594.284269 & + & - & +++ \\
\hline Kaempferitrin & $\mathrm{C}_{27} \mathrm{H}_{30} \mathrm{O}_{14}$ & 578.749072 & + & - & +++ \\
\hline Scutellarein rhamnopyranoside glucopyranoside & $\mathrm{C}_{27} \mathrm{H}_{30} \mathrm{O}_{15}$ & 594.284027 & + & - & +++ \\
\hline Myricetin & $\mathrm{C}_{15} \mathrm{H}_{10} \mathrm{O}_{8}$ & 318.287992 & + & +++ & + \\
\hline Myricetin $O$-arabinogalactoside & $\mathrm{C}_{26} \mathrm{H}_{28} \mathrm{O}_{17}$ & 612.594615 & + & + & +++ \\
\hline Quercetin & $\mathrm{C}_{15} \mathrm{H}_{10} \mathrm{O}_{7}$ & 302.289996 & + & +++ & + \\
\hline Quercitrin/Kaempferol glucoside & $\mathrm{C}_{21} \mathrm{H}_{20} \mathrm{O}_{11}$ & 448.956137 & + & ++ & +++ \\
\hline Rutin & $\mathrm{C}_{27} \mathrm{H}_{30} \mathrm{O}_{16}$ & 610.658348 & + & - & +++ \\
\hline Apigenin & $\mathrm{C}_{15} \mathrm{H}_{10} \mathrm{O}_{5}$ & 270.221390 & + & +++ & + \\
\hline Apigenin- $O$-acetylxyloside & $\mathrm{C}_{23} \mathrm{H}_{22} \mathrm{O}_{11}$ & 474.215366 & + & - & +++ \\
\hline$O$-Caffeoyl-hydroxycitric acid & $\mathrm{C}_{15} \mathrm{H}_{14} \mathrm{O}_{11}$ & 370.137822 & + & - & +++ \\
\hline$O$-Caffeoylshikimic acid & $\mathrm{C}_{16} \mathrm{H}_{16} \mathrm{O}_{8}$ & 336.317691 & + & +++ & + \\
\hline Catechin gallate & $\mathrm{C}_{22} \mathrm{H}_{18} \mathrm{O}_{10}$ & 442.440382 & + & +++ & + \\
\hline Gallocatechin gallate & $\mathrm{C}_{22} \mathrm{H}_{18} \mathrm{O}_{11}$ & 458.434848 & + & +++ & + \\
\hline Ethylchlorogenate & $\mathrm{C}_{18} \mathrm{H}_{22} \mathrm{O}_{9}$ & 382.143465 & + & +++ & + \\
\hline Trimethylhydroxycitric acid & $\mathrm{C}_{9} \mathrm{H}_{14} \mathrm{O}_{8}$ & 250.149487 & + & - & +++ \\
\hline Coumaroylquinic acid & $\mathrm{C}_{16} \mathrm{H}_{18} \mathrm{O}_{8}$ & 338.281091 & + & - & +++ \\
\hline N-Feruloyltyramine & $\mathrm{C}_{18} \mathrm{H}_{19} \mathrm{NO}_{4}$ & 312.252784 & + & + & +++ \\
\hline Cleomiscosin A & $\mathrm{C}_{20} \mathrm{H}_{18} \mathrm{O}_{8}$ & 386.267194 & + & +++ & - \\
\hline Cleomiscosin C/D & $\mathrm{C}_{21} \mathrm{H}_{20} \mathrm{O}_{9}$ & 416.424465 & + & +++ & - \\
\hline \multicolumn{6}{|c|}{ Sterols/Terpenes/Fatty acids } \\
\hline$\beta$-Sitosterol & $\mathrm{C}_{29} \mathrm{H}_{50} \mathrm{O}$ & 414.405049 & + & +++ & - \\
\hline$\beta$-Sitosterol glucoside & $\mathrm{C}_{35} \mathrm{H}_{60} \mathrm{O}_{6}$ & 576.740355 & + & +++ & - \\
\hline Hydroxy taraxeryl acetate & $\mathrm{C}_{32} \mathrm{H}_{52} \mathrm{O}_{3}$ & 484.950167 & + & +++ & - \\
\hline Betulinic acid/Oleanolic acid & $\mathrm{C}_{30} \mathrm{H}_{48} \mathrm{O}_{3}$ & 456.920845 & + & +++ & - \\
\hline Mansonone H & $\mathrm{C}_{15} \mathrm{H}_{14} \mathrm{O}_{4}$ & 258.253920 & + & +++ & - \\
\hline Palmitic acid & $\mathrm{C}_{16} \mathrm{H}_{32} \mathrm{O}_{2}$ & 256.1772030 & + & +++ & - \\
\hline Linolenic acid & $\mathrm{C}_{18} \mathrm{H}_{30} \mathrm{O}_{2}$ & 278.474709 & + & +++ & - \\
\hline Linoleic acid & $\mathrm{C}_{18} \mathrm{H}_{32} \mathrm{O}_{2}$ & 280.3010786 & + & +++ & - \\
\hline Trihydroxy-octadecenoic acid & $\mathrm{C}_{18} \mathrm{H}_{34} \mathrm{O}_{5}$ & 330.3540819 & + & +++ & - \\
\hline Stearic acid & $\mathrm{C}_{18} \mathrm{H}_{36} \mathrm{O}_{2}$ & 284.3896759 & + & +++ & - \\
\hline Docosanoic acid & $\mathrm{C}_{22} \mathrm{H}_{44} \mathrm{O}_{2}$ & 340.35180228 & + & +++ & - \\
\hline Docosanedione & $\mathrm{C}_{22} \mathrm{H}_{42} \mathrm{O}_{2}$ & 338.31881164 & + & +++ & - \\
\hline Methyldocosadienoic acid & $\mathrm{C}_{23} \mathrm{H}_{42} \mathrm{O}_{2}$ & 350.31891388 & + & +++ & - \\
\hline
\end{tabular}

(-) absent, (+) low, $(++)$ moderate, $(+++)$ high. 
Regarding anthocyanins, a mass peak at $m / z 286.17791$ (suggested formula $\mathrm{C}_{15} \mathrm{H}_{10} \mathrm{O}_{6}$ ) was identified as cyanidin. The mass ion peaks at $\mathrm{m} / \mathrm{z} 232.49362$ and 264.26644 for the corresponding molecular formulas $\mathrm{C}_{13} \mathrm{H}_{12} \mathrm{O}_{4}$ and $\mathrm{C}_{10} \mathrm{H}_{16} \mathrm{O}_{8}$, were dereplicated as hibicuslide $\mathrm{C}$ and hibiscus acid hydroxyethyldimethylether, respectively. These were previously reported in $H$. sabdariffa [13]. Furthermore, the suggested molecular formulas $\mathrm{C}_{26} \mathrm{H}_{28} \mathrm{O}_{16}$ and $\mathrm{C}_{26} \mathrm{H}_{28} \mathrm{O}_{15}$ with mass ion peaks at 596.71462 and 580.76147 were characterized as delphinidin 3-sambubioside and cyanidin 3-sambubioside, respectively. Both were previously detected in $H$. sabdariffa [14]. In addition to the aforementioned anthocyanins, several others were tentatively identified by comparing their masses with the reported masses [13,15].

Phenolic and flavonoid classes of compounds such as kaempferol-3-O-glucuronic acid methyl ether and gallocatechin gallate were identified from the mass ion peaks at $\mathrm{m} / \mathrm{z} 476.01280$ and 458.43484 , and corresponded to the molecular formulas $\mathrm{C}_{18} \mathrm{H}_{18} \mathrm{O}_{14}$ and $\mathrm{C}_{22} \mathrm{H}_{18} \mathrm{O}_{11}$, respectively. This is consistent with previous observations in the genus Hibiscus [16]. Another mass ion peak at $\mathrm{m} / \mathrm{z} 302.28999$ (for the predicted formula $\mathrm{C}_{15} \mathrm{H}_{10} \mathrm{O}_{7}$ ) was dereplicated as quercetin. This was previously reported in other Hibiscus species $[17,18]$.
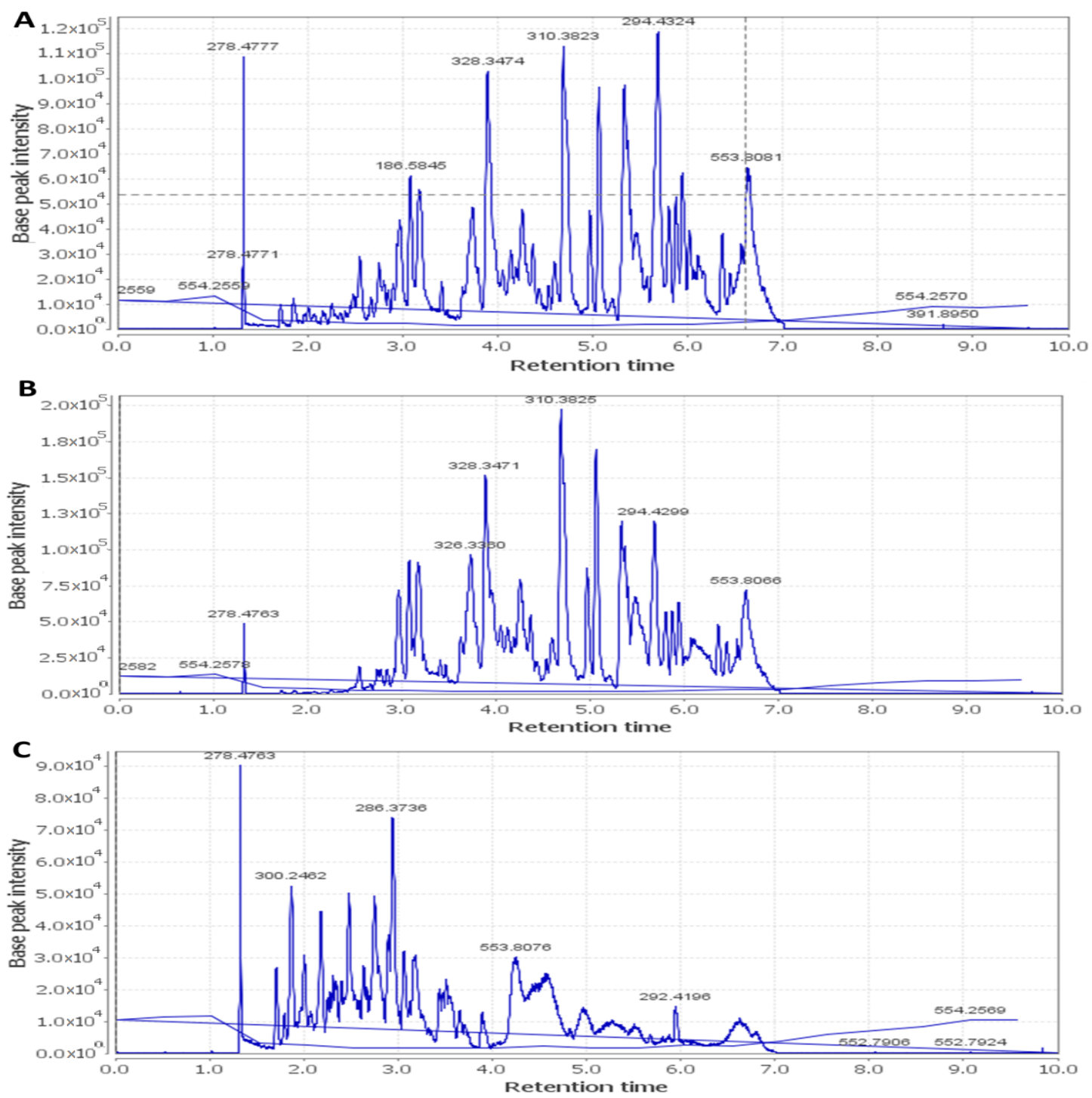

Figure 1. Total ion chromatogram of Hibiscus schizopetalus recorded in negative ionization mode. (A) Ethanolic extract (Et-E); (B) Dichloromethane fraction (DCM-F); (C) n-Butanol fraction (Bu-F). 

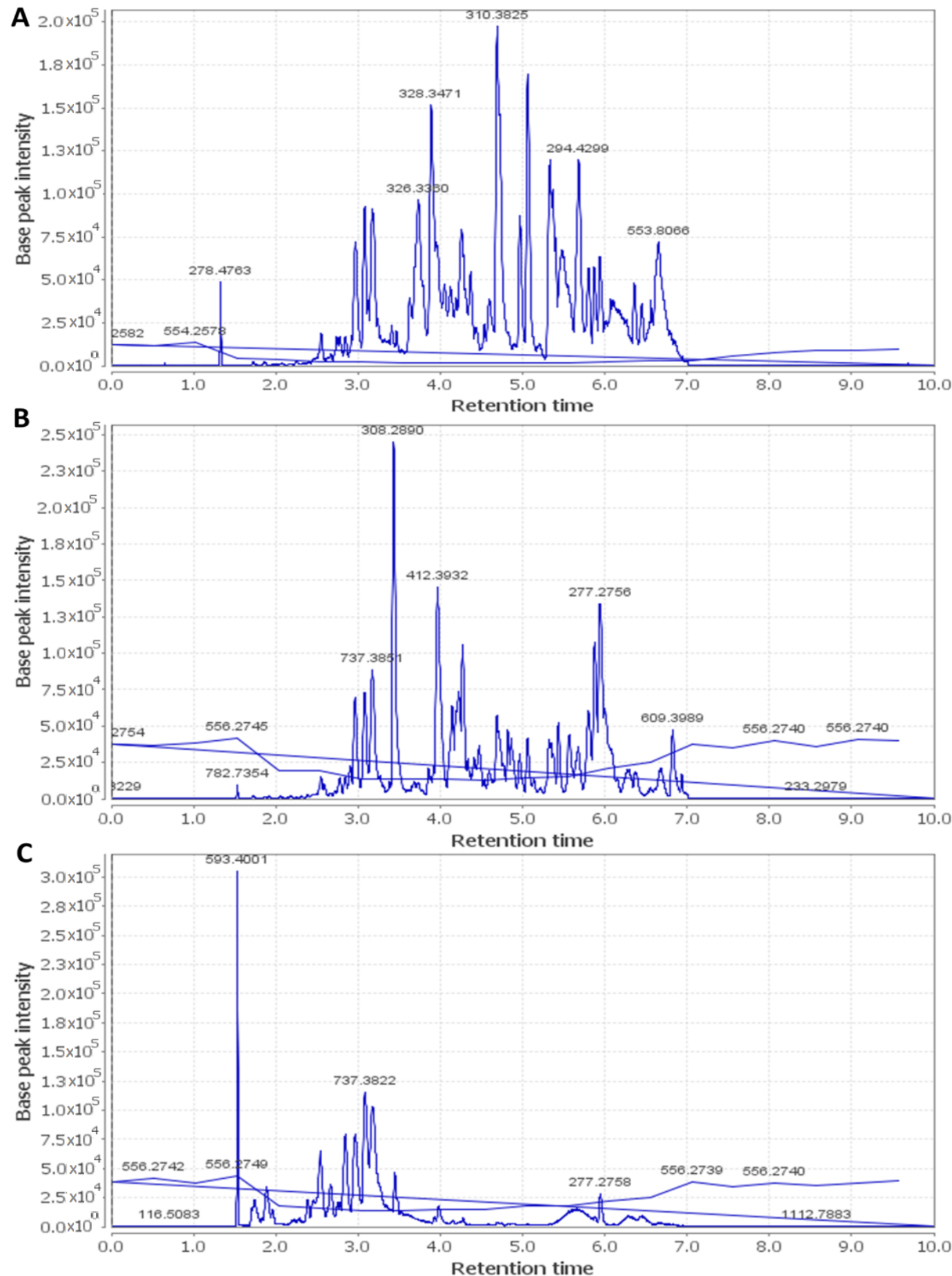

Figure 2. Total ion chromatogram of Hibiscus schizopetalus recorded in positive ionization mode. (A) Ethanolic extract (Et-E); (B) Dichloromethane faction (DCM-F); (C) n-Butanol fraction (Bu-F). $2.0 \times 10^{5}$.

A coumarinolignoid, namely cleomiscosin $\mathrm{A}$, with the molecular formula $\mathrm{C}_{20} \mathrm{H}_{18} \mathrm{O}_{8}$, was characterized from the mass ion peak at $\mathrm{m} / \mathrm{z} 386.26719$. This was previously reported from the root bark of H. syriacus [19]. Similarly, a triterpenoid, namely hydroxy taraxeryl acetate, was detected with the mass ion peak at $m / z$ 484.95016, and corresponded to the molecular formula $\mathrm{C}_{32} \mathrm{H}_{52} \mathrm{O}_{3}$, which was earlier reported in Hibiscus species [20]. Moreover, sterols and fatty acids were also characterized in the extract as $\beta$-sitosterol glucoside and trihydroxy-octadecenoic acid dereplicated from ion peaks at 
$m / z 576.74035$ and 330.354081 , respectively with the proposed molecular formula of $\mathrm{C}_{35} \mathrm{H}_{60} \mathrm{O}_{6}$ and $\mathrm{C}_{18} \mathrm{H}_{34} \mathrm{O}_{5}$, respectively.

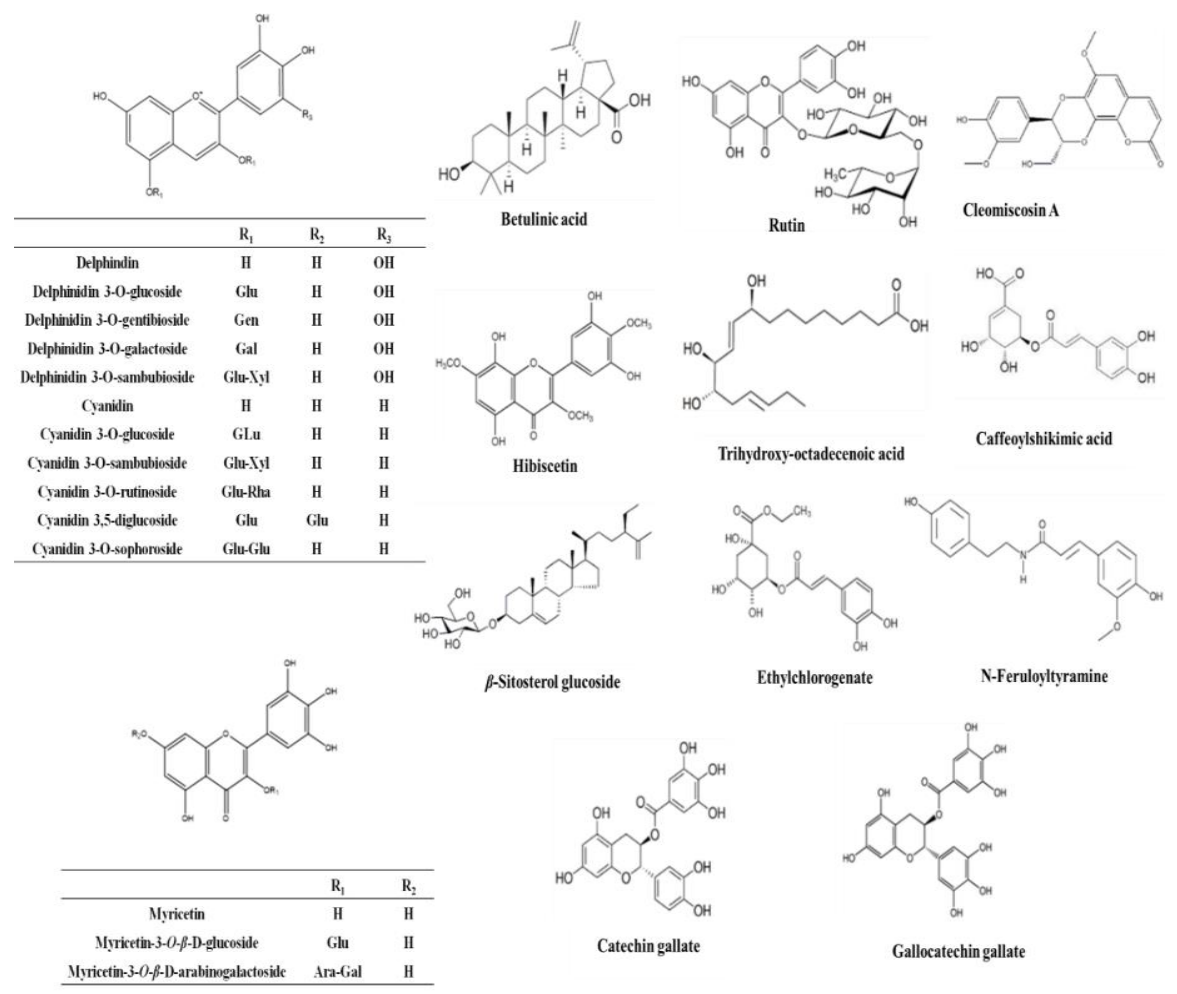

Figure 3. Structures of representative compounds detected in the Hibiscus schizopetalus LC-MS profile.

\section{Discussion}

Medicinal plants and their phytoconstituents are a well-known source of natural anti-infective agents. H. sabdarrifa extracts were reported to exhibit potent activity against HSVI [21]. To the best of our knowledge, there are no studies about the antiviral activity of $H$. schizopetalus. In this study, the Et-E of $H$. schizopetalus showed high activity against adenovirus and CoxB4 virus (using protocol C) and weak to moderate activity against HSVI, HSVII, and HAV. To further investigate whether certain metabolites can account for this antiviral potential, DCM-F and Bu-F were similarly tested. The DCM-F showed the most potent activity against adenovirus and CoxB4 virus.

The antiviral activity of the Et-E of $H$. schizopetalus may be attributed to synergistic effects of anthocyanins, terpenes, sterols, fatty acids, phenolic acids, and flavonoids as detected by LC-MS-MS. The potent antiviral activity of the nonpolar metabolites such as fatty acids and other lipids in DCM-F was previously reported [22-25]. Phytosterols inhibit protease, reverse transcriptase, viral replication, and maturation as well as abate cellular oxidative stress, which can contribute to their antiviral activities [24,26]. For example, the in vitro anti-HIV activity of $\beta$-sitosterol can be attributed to the inhibition of viral protease, in addition to its immunomodulatory actions [26,27]. Taraxerol acetate, a conjugated triterpene, has also showed anti-HSV type II activity [28]. Other triterpenes such as oleanolic acid and its derivatives have well reported antiviral activities and can be used as vaccine adjuvants [29]. Betulinic acid, a pentacyclic triterpenoid, has also been reported to exhibit antiviral activity through inhibition of protease and inhibition of viral replication [27].

Moreover, fatty acids and their derivatives have been reported to display antiviral activities, such as trihydroxy-octadecenoic acid, which is active against influenza A and B viruses [30]. Phenolics such as catechin gallate and gallocatechin gallate are also potent antivirals and can inhibit nanoparticle-based RNA oligonucleotide [27]. In addition, flavonoids such as quercetin, myricetin, and scutellarein have the ability to inhibit viral fusion, integration, reverse transcription, and replication [27]. In addition to 
quercetrin and rutin, coumarinolignoids, such as cleomiscosin, are antivirals that can inhibit reverse transcriptase, viral entry, viral replication, and can potentially regulate the immune response [31,32]. Finally, anthocyanins such as cyanidin, delphinidin, and pelargonidin are antivirals that can disrupt the viral activity and interfere with the viral fusion and attachment [11].

The antibacterial activity of Et-E and its fractions were examined against H. pylori, M. tuberculosis, and MRSA. The DCM-F showed the most potent anti-H. pylori activity followed by Bu-F, and Et-E, as compared to clarithromycin (MIC $1.95 \mu \mathrm{g} / \mathrm{mL}$ ). H. sabdariffa aqueous extracts were also shown to possess anti-H. pylori activity with MIC values ranging from 9.18 to $16.68 \mu \mathrm{g} / \mathrm{mL}$ [33]. In this study, the Bu-F showed the highest anti-mycobacterial and anti-MRSA activity. The anti-MRSA effect has been previously reported for the flowers of other Hibiscus species, such as H. sabdariffa and $H$. rosa sinensis $[9,10]$. The antibacterial activity of the $\mathrm{Bu}-\mathrm{F}$ could be attributed to the flavonoid component, which could inhibit DNA gyrase and impact the bacterial cell wall [34]. Anthocyanins were also shown to have bacteriostatic activity [11].

In antioxidant studies with an ascorbic acid control, methanolic extracts of flowers and leaves of $H$. schizopetalus showed significantly lower values than ascorbic acid when assessed by DPPH radical scavenging and nitric oxide antioxidant assay [35]. In this study, the Bu-F showed the highest antioxidant activity followed by the Et-E and the DCM-F; all three had significantly higher antioxidant activities compared with the ascorbic acid control. The work of Wong et al. on the leaves and flowers of $H$. schizopetalus showed mixed results, with unimpressive antioxidant values when using total phenolic content (TPC) and free radical scavenging (FRS), but better values when using ferrous ion chelating ability and lipid peroxidation inhibition [7]. This ambiguity might be due to the lack of proper controls (no ascorbic acid control or any other controls) and/or the difference in anthocyanin content. The antioxidant activity in the Bu-F could be attributed to gossypitrin [36]. Moreover, anthocyanins such as delphinidin can enhance antioxidant activity by increasing the levels of glutathione, free-radical scavenging, decreasing ROS and lipid peroxidation $[11,37]$.

It is noteworthy that this is the first detailed metabolic profiling of $H$. schizopetalus. Among various metabolites tentatively identified herein, only 22-Hydroxy taraxeryl acetate was isolated before from the leaves in addition to cyanidin 3-sambubioside, quercetin, and rutin, which were previously detected in leaves and stems of H. schizopetalus [3,8].

\section{Materials and Methods}

\subsection{Plant Material and Chemicals}

The aerial parts (leaves, stems, and flowers) of $H$. shizopetalus were collected during the flowering stage in May 2019, from Orman Botanic Garden, Giza, Egypt and authenticated by Mrs. Therese Labib, Botanical specialist and consultant at Orman and Qubba Botanic Gardens. A voucher specimen (26 November 2019) was deposited in the Museum of the Department of Pharmacognosy, College of Pharmacy, Cairo University, Egypt.

We used analytical grade solvents (ethanol, dichloromethane, and $n$-butanol) for plant extraction and fractionation (El-Gomhouria Co., Cairo, Egypt).

The chemicals 2,2' -azino-bis-3-ethylbenzthiazoline-6-sulphonic acid (ABTS), 2,2-diphenyl-1-picrylhydrazyl (DPPH), ascorbic acid, and trichloro acetic acid were obtained from Aldrich Chemicals, U.S.A. Sodium phosphate, ammonium molybdate, potassium persulfate, potassium ferricyanide, and ferric chloride were purchased from El-Nasr Company for Pharmaceutical Chemicals, Egypt. Phosphate buffer was purchased from Bio diagnostic, Egypt. HPLC-grade Acetonitrile and methanol were purchased from SDFCL Fine-Chem Limited, Mumbai, India.

\subsection{Extraction and Fractionation}

The powdered plant material $(1 \mathrm{~kg})$ was extracted in $70 \%$ ethanol $(5 \times 2.5 \mathrm{~L})$ till exhaustion using an Ultra-Turrax ${ }^{\circledR}$ T25 homogenizer (Janke \& Kunkel IKA-Lab., Staufen, Germany). The ethanolic extract 
(Et-E) was evaporated to dryness under reduced pressure (90 g). An aliquot of the dry residue (45 g) was suspended in water $(300 \mathrm{~mL})$ and partitioned, successively, with dichloromethane $(3 \times 500 \mathrm{~mL})$ and $n$-Butanol saturated with water $(3 \times 500 \mathrm{~mL})$. The solvents were evaporated under reduced pressure to give the DCM-F (29 g), and the Bu-F (11 g). The extract and fractions were kept in the desiccator over anhydrous $\mathrm{CaCl}_{2}$.

\subsection{Cytotoxicity Assay}

Vero cells were isolated from kidney epithelial cells extracted from African green monkey (Cercopithecus aethiops). The colorimetric assay of 3-[4-dimethylthiazol-2-yl]-2,5-diphenyl tetrazolium bromide (MTT) was performed spectrophotometrically using a Perkin-Elmer ELISA reader (HTS 7000 plus) at $540 \mathrm{~nm}[38,39]$. The minimum concentration producing alterations in cell morphology is the MNTC. The percentage of cytotoxicity was calculated as $[(A-B) / A] \times 100$, where A and B were the optical densities (OD) of untreated and treated cells, respectively [40]. The $\mathrm{CC}_{50}$ is the concentration that reduced the cell viability by $50 \%$ compared to untreated controls. The $\mathrm{CC}_{50}$ was determined by plotting different concentrations of extracts on the $X$ axis and cell viability on $Y$ axis, where cell viability $(\%)=$ Mean OD/Control OD $\times 100 \%$.

\subsection{Cell Culture and Virus}

The Vero cell line (Cercopithecus aethiops normal adherent kidney epithelial cells, CCL-81) was cultured in RPMI 1640 medium (Gibco, Tunisia) complemented with fetal bovine serum (10\% v/v), L-glutamine $(2 \mathrm{mM})$, penicillin $(100 \mathrm{U} / \mathrm{mL})$, and streptomycin $(100 \mu \mathrm{g} / \mathrm{mL})$ and incubated at $37^{\circ} \mathrm{C}$ in a humidified atmosphere with $5 \% \mathrm{CO}_{2}$. Adenovirus, CoxB4, herpes simplex virus type 1 (HSV-I), herpes simplex virus type 2 (HSV-II), and hepatitis A virus (HAV) were provided by the Laboratory of Virology, Science Way for Scientific Research and Consultations, Faculty of Medicine, Al-Azhar University, Egypt.

\subsection{Antiviral Activity}

Viruses and the Vero cell cultures were treated with the minimum non-toxic concentration of the Et-E using protocols A, B, and C as indicated below [41-44].

Protocol A (virus pretreatment): testing the extract's virucidal activity by exposing the viruses to the extract for one hour at $37^{\circ} \mathrm{C}$, followed by addition of the mixture $(100 \mu \mathrm{L})$ to the cells cultured in a microtiter plate.

Protocol B (cell pretreatment): testing the viral entry into the host cells via blocking the attachment to the cell surface by incubating the extract on Vero cells for one hour followed by the addition of the virus.

Protocol C (post-infection treatment): testing the effect of the extract on viral replication through virus incubation for one hour on Vero cells followed by the addition of the extract.

The viability of infected and non-infected cells was determined using the absorbance values of formazan in an MTT assay. The $\mathrm{IC}_{50}$ is the concentration required to inhibit $50 \%$ of the viral growth. The selectivity index (SI) equals the ratio of the $\mathrm{CC}_{50}$ to the $50 \%$ antiviral concentration (IC $\left.\mathrm{I}_{50}\right)$; $\mathrm{SI}=\mathrm{CC}_{50} / \mathrm{IC}_{50}$. Means of six determinations were calculated.

\subsection{Activity against Helicobacter pylori}

Activity against Helicobacter pylori was assessed using a micro-well dilution method [45]. H. pylori inocula (ATCC 43504) were prepared $\left(10^{6} \mathrm{CFU} / \mathrm{mL}\right)$. The subsequent twofold dilutions $(0.24-125 \mu \mathrm{g} / \mathrm{mL})$ of the tested samples were prepared in DMSO. Clarithromycin and DMSO were used as positive and negative controls, respectively. In a 96-well plate, $40 \mu \mathrm{L}$ of the growth medium (brain heart infusion with $10 \%$ fetal bovine serum) was added then $10 \mu \mathrm{L}$ of inoculum and finally $50 \mu \mathrm{L}$ of the tested samples. The plate was incubated for 3 days at $37^{\circ} \mathrm{C}$ in $5 \% \mathrm{O}_{2}, 10 \% \mathrm{CO}_{2}$, and $85 \% \mathrm{~N}_{2}$ atmosphere. Subsequently, $40 \mu \mathrm{L}$ of MTT $(0.5 \mathrm{mg} / \mathrm{mL})$ was added and incubated for $30 \mathrm{~min}$. The percentage inhibition of bacterial 
growth by different concentrations of each sample was calculated: $\%$ inhibition $=\left[\left(\mathrm{Abs}_{\mathrm{control}}-\mathrm{Abs}_{\text {sample }}\right)\right.$ $\times 100 / \mathrm{Abs}_{\mathrm{control}}$. The minimum concentration required for the inhibition of bacterial growth (MIC) and the concentration required for inhibition of $90 \%$ of the bacterial growth (MIC90) were determined from the corresponding dose-response curve. The MTT assay was done using an automatic BioTek plate reader at $620 \mathrm{~nm}$.

\subsection{Anti-Mycobacterial Activity}

The anti-mycobacterial activity against $M$. tuberculosis (M. Tub ATCC 27294) was detected using the Microplate Alamar Blue Assay (MABA) [46]. Isoniazid was used as a reference drug. Serial dilutions $(0.24-125 \mu \mathrm{g} / \mathrm{mL})$ of the tested samples and isoniazid, dissolved in DMSO, were prepared in the microplate then $0.1 \mathrm{~mL}$ of a $M$. tuberculosis inoculum $\left(10^{5} \mathrm{CFU} / \mathrm{mL}\right)$ was added. Plates were incubated at $37^{\circ} \mathrm{C}$ for 4 days, then $20 \mu \mathrm{L}$ of Alamar Blue solution and $12.5 \mu \mathrm{L}$ of $20 \%$ Tween 80 were added. The plates were re-incubated at $37^{\circ} \mathrm{C}$ for $24 \mathrm{~h}$. The color intensity was measured using an ELISA microplate reader at $590 \mathrm{~nm}$. The experiment was done in triplicates.

\subsection{Activity against Methicillin-Resistant Staphylococcus aureus (MRSA)}

The anti-MRSA activity (MRSA ATCC 27294) was assessed using the microdilution method in the presence of tetrazolium salts [47]. Vancomycin was used as a reference drug. In a 96-well microplate, $40 \mu \mathrm{L}$ of the growth medium (brain heart infusion; BHI), plus 10\% Fetal Bovine Serum (FBS), $10 \mu \mathrm{L}$ of the inoculum $\left(10^{6} \mathrm{CFU} / \mathrm{mL}\right)$, and $50 \mu \mathrm{L}$ of the sample dilutions $(0.24-125 \mu \mathrm{g} / \mathrm{mL})$ were added. The plates were incubated at $37^{\circ} \mathrm{C}$ for $24 \mathrm{~h}$. To each well, $40 \mu \mathrm{L}$ of XTT were added and incubated for $1 \mathrm{~h}$ in the dark at $37^{\circ} \mathrm{C}$. For each well, the color intensity was measured at $492 \mathrm{~nm}$.

\subsection{Antioxidant Activity}

\section{A. Total antioxidant capacity assay (TAC).}

The antioxidant activity of the samples was assessed using the phosphomolybdenum method [48,49]. Absorbance was measured at $695 \mathrm{~nm}$ after incubation at $95{ }^{\circ} \mathrm{C}$ for $150 \mathrm{~min}$. The TAC was expressed in ascorbic acid equivalents (AAE) ( $\mu \mathrm{mol} / \mathrm{g}$ of extract).

B. 2,2'-azino-bis-3-ethylbenzthiazoline-6-sulphonic acid (ABTS) radical scavenging assay.

The ABTS radical scavenging assay was used to assess the free radical scavenging activity of the Hibiscus extract and its fractions [48,49]. Measurements were carried out at $734 \mathrm{~nm}$. The ABTS radical scavenging ability was expressed as IC50 $(\mathrm{mg} / \mathrm{mL})$. Ascorbic acid was used as a standard.

\section{2,2-diphenyl-1-picryl-hydrazyl (DPPH) radical scavenging assay.}

The anti-oxidant activity was measured as previously described [49] Absorbance was measured at $517 \mathrm{~nm}$. Ascorbic acid was used as standard. IC50 was determined using the equation [(Ac $-\mathrm{As}) / \mathrm{Ac}] \times 100$. Ac is the control absorbance (DPPH solution without test sample) while As is the sample absorbance (DPPH solution in addition to the extract or the standard). The IC50 is the concentration that produces $50 \%$ inhibition of absorbance at the indicated wavelength.

\section{Reducing power assay.}

The reducing power was assessed by the evaluating the ability of the samples to change potassium ferricyanide to potassium ferrocyanide. Absorbance was measured at $700 \mathrm{~nm}[48,49]$. The EC50 is the effective concentration $(\mathrm{mg} / \mathrm{mL})$ acquired from linear regression analysis with an absorbance of 0.5 . The effective concentration providing an absorbance of 0.5 was calculated. Ascorbic acid was used as a standard.

Experiments for antioxidants were done in triplicates and means were calculated. 


\subsection{HPLC-HR-ESI-MS}

The crude methanolic extract and fractions for mass spectrometry were prepared at $1 \mathrm{mg} / \mathrm{mL}$. Metabolomic analysis of the samples was done using LC-HR-ESI-MS [50,51]. We used an Acquity Ultra Performance Liquid Chromatography system that was connected to a Synapt G2 HDMS quadrupole time-of-flight hybrid mass spectrometer (Waters, Milford, CT, USA). Positive and negative ESI ionization modes were used to perform the high-resolution mass spectrometry coupled with a spray voltage of $4.5 \mathrm{kV}$, capillary temperature of $320^{\circ} \mathrm{C}$, and a mass range from $\mathrm{m} / \mathrm{z} 150-1500$.

The data were imported and analyzed using MZmine 2.20 [52]. The mass ion peaks in positive and negative ionization mode data sets were dereplicated against the databases of the Dictionary of Natural Products.

\subsection{Statistical Analysis}

Data analysis was done using analysis of variance (ANOVA). The significance of differences between means was done using Duncan's multiple range tests at $p<0.05$.

\section{Conclusions}

H. schizopetalus is endowed with a lot of chemical compounds (more than 60 metabolites) that could be clinically used in fighting viruses, such as adenoviruses, HSVI, and CoxB4. They can also be used as effective therapies against antibiotic resistant pathogens such as M. tuberculosis, MRSA, and H. pylori. Finally, they can be potent antioxidants that can protect cells from free radical damage in cancer, heart diseases, and other serious health conditions.

Author Contributions: All authors contributed to the conceptualization, experimental design and execution, data curation and analysis, project administration, writing the original draft, and editing of the manuscript. All authors have read and agreed to the published version of the manuscript.

Funding: This research received no external funding.

Acknowledgments: We are grateful to Martin Müller and Markus Krischke for their help with LC-MS.

Conflicts of Interest: The authors declare no conflict of interest.

\section{References}

1. Khameneh, B.; Iranshahy, M.; Soheili, V.; Bazzaz, B.S.F. Review on plant antimicrobials: A mechanistic viewpoint. Antimicrob. Resist. Infect. Control 2019, 8, 118. [CrossRef] [PubMed]

2. Chan, E.W.; Wong, S.; Chan, H. A review on the phytochemistry and pharmacology of two Hibiscus species with spectacular flower colour change: H. tiliaceus and H. mutabilis. Int. J. Pharmacogn. Phytochem. Res. 2016, 8, 1200-1208.

3. Abdelhafez, O.H.; Othman, E.M.; Fahim, J.R.; Desoukey, S.Y.; Pimentel-Elardo, S.M.; Nodwell, J.R.; Schirmeister, T.; Tawfike, A.; Abdelmohsen, U.R. Metabolomics analysis and biological investigation of three Malvaceae plants. Phytochem. Anal. 2020, 31, 204-214. [CrossRef] [PubMed]

4. Pal, S.; Sarkar, J.; Bhattacharya, S.; Biswas, M. Thi layer chromatographic studies ad assessme $t$ of a ti-i flammatory effect of Hibiscus schizopetalus leaf extracts in rats. Pharmacologyonline 2011, 2, 1431-1436.

5. Wong, S.K.; Lim, Y.Y.; Chan, E.W.C. Antioxidant properties of Hibiscus: Species variation, altitudinal change, coastal influence and floral colour change. J. Trop. For. Sci. 2009, 21, 307-315.

6. Zahid, H.; Rizwani, G.H. Antimicribial efficacy of Hibiscus schizopetalus (Mast) Hook. Hamdard Med. 2016, 59, 4.

7. Wong, S.; Chan, E.W.; Chan, H. A review on the phytochemistry and pharmacology of two lesser-known Hibiscus species: H. taiwanensis and H. schizopetalus. Int. J. Pharmacogn. Phytochem. Res. 2016, 8, 1341-1346.

8. Jose, E.; Vijayan, K. New taraxerane esters from Hibiscus schizopetalus leaves. Indian J. Chem. 2006, 45B, $1328-1331$. [CrossRef]

9. Hayati, Z.; Yulia, W.; Karmil, T.F.; Azmy, A. Anti-bacterial activity of rosella flowers extract (Hibiscus sabdariffa linn) in inhibiting bacterial growth methicillin-resistant Staphylococcus aureus. In Proceedings of the Annual International Conference, Syiah Kuala University-Life Sciences \& Engineering Chapter, Banda Aceh, Indonesia, 22-24 November 2012. 
10. Arullappan, S.; Zakaria, Z.; Basri, D.F. Preliminary screening of antibacterial activity using crude extracts of Hibiscus rosa sinensis. Trop. Life Sci. Res. 2009, 20, 109.

11. Pour, P.M.; Fakhri, S.; Asgary, S.; Farzaei, M.H.; Echeverria, J. The signaling pathways, and therapeutic targets of antiviral agents: Focusing on the antiviral approaches and clinical perspectives of anthocyanins in the management of viral diseases. Front. Pharmacol. 2019, 10, 1207. [CrossRef]

12. Ito, T.; Masubuchi, M. Dereplication of microbial extracts and related analytical technologies. J. Antibiot. 2014, 67, 353-360. [CrossRef] [PubMed]

13. Salem, M.A.; Michel, H.E.; Ezzat, M.I.; Okba, M.M.; L-Desoky, A.M.E.; Mohamed, S.O.; Ezzat, S.M. Optimization of an Extraction solvent for angiotensin-converting enzyme inhibitors from hibiscus sabdariffa 1. based on its UPLC-MS/MS metabolic profiling. Molecules 2020, 25, 2307. [CrossRef] [PubMed]

14. Obouayeba, A.; Djyh, N.; Diabate, S.; Djaman, A.; N'guessan, J.; Kone, M.; Kouakou, T. Phytochemical and antioxidant activity of Roselle (Hibiscus sabdariffa L.) petal extracts. Res. J. Pharm. Biol. Chem. Sci. 2014, 5, 1453-1465.

15. Rasheed, D.M.; Porzel, A.; Frolov, A.; el Seedi, H.R.; Wessjohann, L.A.; Farag, M.A. Comparative analysis of Hibiscus sabdariffa (roselle) hot and cold extracts in respect to their potential for $\alpha$-glucosidase inhibition. Food Chem. 2018, 250, 236-244. [CrossRef]

16. Da-Costa-Rocha, I.; Bonnlaender, B.; Sievers, H.; Pischel, I.; Heinrich, M. Hibiscus sabdariffa L.-A phytochemical and pharmacological review. Food Chem. 2014, 165, 424-443. [CrossRef]

17. Sharma, M.C.; Smita, S.; Kohli, D.V. Phytochemical and anti-ulcer investigations of 95\% ethanolic-benzenechloroform leaf extract of Hibiscus tiliaceus Linn. in Albino rat model. Ann. Biol. Res. 2010, 1, 15-20.

18. Barve, V.H.; Hiremath, S.; Pattan, S.; Pal, S. Phytochemical and pharmacological evaluation of Hibiscus mutabilis leaves. J. Chem. Pharm. Res. 2010, 2, 300-309.

19. Yun, B.-S.; Lee, I.-K.; Ryoo, I.-J.; Yoo, I.-D. Coumarins with monoamine oxidase inhibitory activity and antioxidative coumarino-lignans from hibiscus s yriacus. J. Nat. Prod. 2001, 64, 1238-1240. [CrossRef]

20. Salem, M.Z.; Olivares-Pérez, J.; Salem, A. Studies on biological activities and phytochemicals composition of Hibiscus species-A review. Life Sci. J. 2014, 11, 1-8.

21. Torky, Z.A.; Hossain, M.M. Pharmacological evaluation of the hibiscus herbal extract against herpes simplex virus-type 1 as an antiviral drug in vitro. Int. J. Virol. 2017, 13, 68-79. [CrossRef]

22. Thormar, H.; Isaacs, C.E.; Brown, H.R.; Barshatzky, M.R.; Pessolano, T. Inactivation of enveloped viruses and killing of cells by fatty acids and monoglycerides. Antimicrob. Agents Chemother. 1987, 31, 27-31. [CrossRef] [PubMed]

23. Rezanka, T.; Siristova, L.; Sigler, K. Sterols and triterpenoids with antiviral activity. Anti-Infect. Agents Med. Chem. (Former. Curr. Med. Chem.-Anti-Infect. Agents) 2009, 8, 193-210. [CrossRef]

24. Khwaza, V.; Oyedeji, O.O.; Aderibigbe, B.A. Antiviral activities of oleanolic acid and its analogues. Molecules 2018, 23, 2300. [CrossRef]

25. Librán-Pérez, M.; Pereiro, P.; Figueras, A.; Novoa, B. Antiviral activity of palmitic acid via autophagic flux inhibition in zebrafish (Danio rerio). Fish Shellfish Immunol. 2019, 95, 595-605. [CrossRef]

26. Parvez, M.K.; Alam, P.; Arbab, A.H.; Al-Dosari, M.S.; Alhowiriny, T.A.; Alqasoumi, S.I. Analysis of antioxidative and antiviral biomarkers $\beta$-amyrin, $\beta$-sitosterol, lupeol, ursolic acid in Guiera senegalensis leaves extract by validated HPTLC methods. Saudi Pharm. J. 2018, 26, 685-693. [CrossRef]

27. Islam, M.T.; Sarkar, C.; El-Kersh, D.M.; Jamaddar, S.; Uddin, S.J.; Shilpi, J.A.; Mubarak, M.S. Natural products and their derivatives against coronavirus: A review of the non-clinical and pre-clinical data. Phytother. Res. 2020, 34, 2471-2492. [CrossRef]

28. Kuljanabhagavad, T.; Suttisri, R.; Pengsuparp, T.; Ruangrungsi, N. Chemical structure and antiviral activity of aerial part from Laggera pterodonta. J. Health Res. 2009, 23, 175-177.

29. Masullo, M.; Pizza, C.; Piacente, S. Oleanane derivatives for pharmaceutical use: A patent review (2000-2016). Expert Opin. Ther. Pat. 2017, 27, 237-255. [CrossRef] [PubMed]

30. Nagai, T.; Kiyohara, H.; Munakata, K.; Shirahata, T.; Sunazuka, T.; Harigaya, Y.; Yamada, H. Pinellic acid from the tuber of Pinellia ternata Breitenbach as an effective oral adjuvant for nasal influenza vaccine. Int. Immunopharmacol. 2002, 2, 1183-1193. [CrossRef]

31. Yadav, D.K.; Meena, A.; Srivastava, A.; Chanda, D.; Khan, F.; Chattopadhyay, S. Development of QSAR model for immunomodulatory activity of natural coumarinolignoids. Drug Des. Dev. Ther. 2010, 4, 173. 
32. Teponno, R.B.; Kusari, S.; Spiteller, M. Recent advances in research on lignans and neolignans. Nat. Prod. Rep. 2016, 33, 1044-1092. [CrossRef] [PubMed]

33. Hassan, S.T.; Berchová, K.; Majerová, M.; Pokorná, M.; Švajdlenka, E. In vitro synergistic effect of Hibiscus sabdariffa aqueous extract in combination with standard antibiotics against Helicobacter pylori clinical isolates. Pharm. Biol. 2016, 54, 1736-1740. [CrossRef] [PubMed]

34. Donkor, S.; Larbie, C.; Komlaga, G.; Emikpe, B.O. Phytochemical, antimicrobial, and antioxidant profiles of Duranta erecta L. parts. Biochem. Res. Int. 2019, 2019, 1-11. [CrossRef] [PubMed]

35. Zahid, H.; Rizwani, G.H.; Shareef, H.; Ali, S.T. Antioxidant and urease inhibition activity of methanol extract of Hibiscus schizopetalus (Mast) Hook. J. Pharmacogn. Phytochem. 2014, 2, 7-11.

36. François-Haugrin, F.; Monan, M.; Nossin, E.; Smith-Ravin, J.; Marcelin, O. Antioxidant activity of an isomer of gossypitrin (gossypetin-3'-O-glucoside) isolated in the petals of Talipariti elatum Sw., and determination of total phenolic content of the total flower. J. Pharmacogn. Phytochem. 2016, 5, 200.

37. Masheta, D.Q.; Al-Azzawi, S.K. Antioxidant and Anti-Inflammatory Effects of Delphinidin on Glial Cells and Lack of Effect on Secretase Enzyme. In IOP Conference Series: Materials Science and Engineering; IOP Publishing: Bristol, UK, 2018.

38. Elaissi, A.; Rouis, Z.; Salem, N.A.B.; Mabrouk, S.; ben Salem, Y.; Salah, K.B.H.; Aouni, M.; Farhat, F.; Chemli, R.; Harzallah-Skhiri, F. Chemical composition of 8 Eucalyptus species' essential oils and the evaluation of their antibacterial, antifungal and antiviral activities. BMC Complement. Altern. Med. 2012, 12, 81. [CrossRef]

39. Takeuchi, H.; Baba, M.; Shigeta, S. An application of tetrazolium (MTT) colorimetric assay for the screening of anti-herpes simplex virus compounds. J. Virol. Methods 1991, 33, 61-71. [CrossRef]

40. Goodger, J.Q.; Woodrow, I.E. $\alpha, \beta$-Unsaturated monoterpene acid glucose esters: Structural diversity, bioactivities and functional roles. Phytochemistry 2011, 72, 2259-2266. [CrossRef]

41. Gong, E.Y. (Ed.) Antiviral Methods and Protocols; Springer: Berlin/Heidelberg, Germany, 2013.

42. Ocazionez, R.E.; Meneses, R.; Torres, F.Á.; Stashenko, E. Virucidal activity of Colombian Lippia essential oils on dengue virus replication in vitro. Memórias Inst. Oswaldo Cruz 2010, 105, 304-309. [CrossRef]

43. Gescher, K.; Kühn, J.; Hafezi, W.; Louis, A.; Derksen, A.; Deters, A.; Lorentzen, E.; Hensel, A. Inhibition of viral adsorption and penetration by an aqueous extract from Rhododendron ferrugineum L. as antiviral principle against herpes simplex virus type-1. Fitoterapia 2011, 82, 408-413. [CrossRef]

44. Okba, M.M.; el Gedaily, R.A.; Ashour, R.M. UPLC-PDA-ESI-qTOF-MS profiling and potent anti-HSV-II activity of Eucalyptus sideroxylon leaves. J. Chromatogr. B 2017, 1068, 335-342. [CrossRef]

45. Bonacorsi, C.; Raddi, M.S.G.; Carlos, I.Z.; Sannomiya, M.; Vilegas, W. Anti-Helicobacter pylori activity and immunostimulatory effect of extracts from Byrsonima crassa Nied (Malpighiaceae). BMC Complement. Altern. Med. 2009, 9, 1-7. [CrossRef] [PubMed]

46. Lu, Y.; Zheng, M.; Wang, B.; Fu, L.; Zhao, W.; Li, P.; Xu, J.; Zhu, H.; Jin, H.; Yin, D. Clofazimine analogs with efficacy against experimental tuberculosis and reduced potential for accumulation. Antimicrob. Agents Chemother. 2011, 55, 5185-5193. [CrossRef] [PubMed]

47. Tunney, M.M.; Ramage, G.; Field, T.R.; Moriarty, T.F.; Storey, D.G. Rapid colorimetric assay for antimicrobial susceptibility testing of Pseudomonas aeruginosa. Antimicrob. Agents Chemother. 2004, 48, 1879-1881. [CrossRef] [PubMed]

48. El-Shiekh, R.A.; Ashour, R.M.; Abd El-Haleim, E.A.; Ahmed, K.A.; Abdel-Sattar, E. Hibiscus sabdariffa L.: A potent natural neuroprotective agent for the prevention of streptozotocin-induced Alzheimer's disease in mice. Biomed. Pharmacother. 2020, 128, 110303. [CrossRef]

49. Chaouche, T.M.; Haddouchi, F.; Ksouri, R.; Atik-Bekkara, F. Evaluation of antioxidant activity of hydromethanolic extracts of some medicinal species from South Algeria. J. Chin. Med. Assoc. 2014, 77, 302-307. [CrossRef]

50. Abdelmohsen, U.R.; Cheng, C.; Viegelmann, C.; Zhang, T.; Grkovic, T.; Ahmed, S.; Quinn, R.J.; Hentschel, U.; Edrada-Ebel, R. Dereplication strategies for targeted isolation of new antitrypanosomal actinosporins A and B from a marine sponge associated-Actinokineospora sp. EG49. Mar. Drugs 2014, 12, 1220-1244. [CrossRef] 
51. Gamaleldin, N.M.; Bakeer, W.; Sayed, A.M.; Shamikh, Y.I.; El-Gendy, A.O.; Hassan, H.M.; Horn, H.; Abdelmohsen, U.R.; Hozzein, W.N. Exploration of chemical diversity and antitrypanosomal activity of some red sea-derived actinomycetes using the OSMAC approach supported by LC-MS-based metabolomics and molecular modelling. Antibiotics 2020, 9, 629. [CrossRef]

52. Tawfike, A.; Attia, E.Z.; Desoukey, S.Y.; Hajjar, D.; Makki, A.A.; Schupp, P.J.; Edrada-Ebel, R.; Abdelmohsen, U.R. New bioactive metabolites from the elicited marine sponge-derived bacterium Actinokineospora spheciospongiae sp. nov. AMB Express 2019, 9, 12. [CrossRef]

Publisher's Note: MDPI stays neutral with regard to jurisdictional claims in published maps and institutional affiliations.

(C) 2020 by the authors. Licensee MDPI, Basel, Switzerland. This article is an open access article distributed under the terms and conditions of the Creative Commons Attribution (CC BY) license (http://creativecommons.org/licenses/by/4.0/). 